\title{
Development of CLOSER Model in Applying SLIM Teaching Material during Teachers' Training
}

\author{
Eka Dewi Nuraeni, Soewarto Hardhienata, Rita Retnowati \\ Post Graduate Program, Universitas Pakuan Bogor, Indonesia
}

\begin{abstract}
The objectives of this research are: 1) to develop CLOSER model training (Cluster Learning, On the job learning, Sharing Experience); 2) develop SLIM teaching materials (Self Learning Instrument and Material); 3) using CLOSER training model with SLIM teaching materials in teacher training at private Islamic Junior High School in Karawang, Indonesia to improve reaction, learning, behavior change and impact levels.

The limited pilot phase is given to 14 teachers and evaluated at the reaction, learning and behavior change level; and expert judgment. The operational stage was expanded to 33 participants from nine Islamic schools in Karawang and evaluated at the reaction, learning, behavior change and impact level and expert judgment.

The results showed that CLOSER training with SLIM teaching materials resulted in reaction level in the form of the value of satisfaction, effectiveness, high relevance. At the level of learning, there is a significant increase in knowledge as well as the achievement of targeted competencies. At the levels of behavior change, 100\% of participants are making action plans, applying training results, disseminating them, identifying and resolving obstacles, identifying support factors, and willing to attend other training at own cost. At the outcome level, $85 \%$ of participants experienced significant changes with the impact on teachers as indicated by improved teaching and motivation skills.
\end{abstract}

Keywords: CLOSER (Cluster Learning, on the job learning, Sharing Experience), SLIM (Self Learning Instrument and Material), Teachers', Training

\section{INTRODUCTION}

As a follow-up of the teacher certification, Indonesian Ministry of Education conducts the Teacher Competency Test to see if a teacher has fulfilled four competency domains that teachers must possess, namely pedagogical competence, academic competence, institutional competence, and professional competence.

The result of competency test shows that there are still many teachers who have not reached the established competency standard, that is the average of 2013 Teachers Competency Test in Indonesia only 4.25.In addition, classroom learning is more dominated by one-way lectures from teachers where a very rare question and answer set is found. This reflects many teachers still do not seek to improve and update their professionalism.

To improve the competence and professionalism of teachers, the government has developed a series of activities related to teacher performance assessment and continuing teacher professional development aiming to minimize the gap between the competencies of the present teacher and what the future demands related to his profession. Continuing teacher professional development can be pursued through self-development, innovative works, and scientific publications.

Problems of teacher quality also occur in Karawang, regency especially teachers in private Islamic schools that have grown rapidly in recent years. From the results of problem identification, it can be concluded that there is a need for an effective form of teacher training. The availability of teaching materials is also needed to help achieve the training objectives.

Teachers need the job training as it starts to be applied to some types of training with the stages of the material delivered by the trainer or tutor. To improve this training, researchers developed CLOSER model consisting of three stages of training that are cluster learning, on the job learning and sharing experience. The modules or teaching materials are an important part of the training. The commonly used teaching materials are handouts or printouts from presentation slides. The available modules are 
usually a compilation of training materials delivered by the trainer or tutor. To improve the training module, the researcher develops SLIM (Self Learning Instrument and Material)

In response to the training needs, a CLOSER model was developed using SLIM teaching materials for teacher training at Islamic Junior High School in Karawang regency.

The objectives of this research are:

1. Developing a CLOSE model in teacher training at Islamic Junior High School Karawang.

2. Developing the form of SLIM teaching materials in training the teachers of private Islamic Junior High School.

3. Using the CLOSE model with SLIM teaching materials in teacher training at Islamic Junior High School to improve reaction level, learning level, behavior change level and impact levels.

\section{LiterATURE REVIEW}

Kaswan (2011) argued that training is the process of increasing the knowledge and skills of employees, which may also include changing attitudes so that employees can do their work more effectively. According to Rothwell \& Kazanas (2003) training is an organized learning activity that is able to improve individual performance through changes in knowledge, skills, or attitudes. Amstrong (2006) explains that training is the use of systematic and planned instructional activities to improve learning. Training involves the use of formal processes to provide knowledge and help participants acquire the skills necessary to do their job satisfactorily.

Sims (2002) mentions that training and development methods consist of 1). on the job training: is an out-of-class training, which directly links training materials with performance in tasks; 2). programmed or self-instruction, a training that allows participants to develop learning independently, from simple to complex topics; 3) computer-based training, 4) distance learning, 5) case study, 6) classroom instruction; 7) demonstration, behavior modeling and role-plays.

Furthermore, Sim states that each of the methods described above has weaknesses and strengths. Thus, the selection of training methods is done by 1) a systematic analysis to determine appropriate training methods; 2) combining several training models to obtain a complete and efficient training system.

Wiggins and Jay McTighe (2011) illustrate that successful learning begins with clarity of expected learning outcomes and evidence to show that learning has occurred, which is also shown in the teaching materials. Therefore, the instructional material design is done backward, starting from goal setting, determining the task and followed by the development of the topic or activity. This reverse design will result in shorter and longer term goals that are clearer, more precise judgments and more targeted instruction.

The same thing is stated by Branch (2009) that instructional design is a recurring process of planning performance goals, choosing learning strategies, choosing media and selecting or creating materials, and evaluation. In order to avoid instructional design based on the content resulting in a gap between general and objective purposes, the designer must work backward from the desired result and destination sequence, then the external conditions to support the internal conditions for learning.

The design of the research and development model used under the Borg \& Gall design is modified into three main stages, namely, model development, limited field testing and extensive trials. According to Mulyatiningsih (2013) Borg \& Gall's design consists of 1) selecting and collecting information to observe development needs; 2) planning prototypes of components to be developed; 2) developing early prototypes; 4) conducting a limited trial of the initial model; 5) revising the initial model, based on the results of a limited trial and data analysis performed on the initial model; 6) conducting a limited field trial, 7) revising the product; 8) conducting field trials operationally and broadly; 9) a final revision of the model is made; and, 10) disseminating.

Based on the results of needs analysis and identification of current conditions, a product will be developed to meet the conditions to be achieved:

1. CLOSER: The CLOSER combination results are briefly composed of Cluster learning stages, on the job learning and Sharing Experience.

2. SLIM: SLIM is a teaching material that contains steps of activities, instruments, worksheets and reading materials that will help teachers step by step to achieve training objectives. After gaining an understanding of the concept, the teacher is guided to plan and execute it. The compiled SLIM refers to the design of backward development of teaching materials from Wiggins and Jay McTighe. 


\section{METHODOLOGY}

Research was conducted in Karawang Regency centered in Islamic Junior High School Karawang. Subject or population is non-civil servant teachers teaching in Islamic Junior High School in Karawang regency.

The design of the research and development model used is based on Borg \& Gall (1996) design model which consists of three main stages, namely:

\subsection{Model Development Stage}

This stage begins by selecting and gathering information, observing development needs; planning prototypes of components to be developed and developing early prototypes. CLOSER training design and indicators are derived from the conceptual definition of training. At this stage will be generated CLOSER-SLIM Version 1. The initial design of CLOSER training and SLIM teaching materials is reviewed and critiqued using Delphi techniques through expert judgment. The product will then be revised based on the input of the expert team. The Delphi technique is also used to validate Kirkpatrick's evaluation instruments.

The experts involved are a team of experts in the Professional Development for Personnel Education (Pro-DEP) program, Australian Education Partnership with Indonesia-School System Quality (AEPISSQ). The model was revised based on the results of a limited trial and data analysis performed on the initial model resulting in CLOSER-SLIM Version 2.

\subsection{Conducting a Limited Field Trial and Revising the Product}

A limited field trial was conducted for 14 teachers. At the end of this stage, the expert team re-reviews and provides input through the second Delphi Test. The product is then revised based on the evaluation results and input from the expert team so that the CLOSER-SLIM Version 3 will be produced. The revised products are used in the broader operational field trials.

\subsection{Conducting Field Trials Operationally and More Widely (Operational Field Test)}

Researchers conducted extensive operational field trials to teachers of private Islamic Junior High School in Karawang regency with a total sample of 33 people from nine schools. Based on experimental results and assessments of experts, improvements were made to CLOSER training and SLIM teaching materials. At this stage, it will be generated a CLOSER-SLIM Version 4. Furthermore, dissemination to various parties both through publicity and other diffusion ways. The criteria of success according to the final goal in this research and development is to improve teachers' ability in managing to learn through CLOSER training and using SLIM teaching materials. These success criteria can be seen in the table below.

Table1. Evaluation Instruments and Success Criteria

\begin{tabular}{|c|c|c|c|}
\hline Instruments & Code & Stages** & Success Criteria \\
\hline \multicolumn{4}{|l|}{ Reaction } \\
\hline Smile sheet & A1 & $\mathrm{CL}$ & $>90 \%$ of participants feel very happy or happy \\
\hline $\begin{array}{l}\text { Training Evaluation by } \\
\text { participants }\end{array}$ & A3 & CL & $\begin{array}{l}\text { Effectiveness }>80 \% \\
\text { Relevance }>80 \%\end{array}$ \\
\hline \multicolumn{4}{|l|}{ Learning } \\
\hline Pre-Test/Post test & B1 & $\begin{array}{l}\text { CL } \\
\text { SE }\end{array}$ & $\begin{array}{l}\text { T-test }<0.05 \text { ( significant) } \\
\text { Effect size }>0.8 \text { (big) }\end{array}$ \\
\hline Supervision of implementation & $\mathrm{B} 2$ & $\mathrm{O}$ & $\begin{array}{l}>80 \% \text { implements training on the job learning } \\
\text { The average result of supervision on good } \\
\text { criterion }(66-80 \%) \text { or very good }(81 \%-100 \%)\end{array}$ \\
\hline $\begin{array}{l}\text { Self-assessment and assessment } \\
\text { of mentor / supervisor }\end{array}$ & B3 & $\mathrm{O}$ & $\begin{array}{l}>80 \% \text { of the participants who implemented the } \\
\text { training were declared competent }\end{array}$ \\
\hline \multicolumn{4}{|l|}{ Behavior Changing } \\
\hline Group discussion & $\mathrm{C} 1$ & SE & \multirow{3}{*}{$\begin{array}{l}>80 \% \text { of participants implement follow-up plans } \\
\text { There are behavioral changes (continuing to } \\
\text { implement activities, overcoming barriers with } \\
\text { available support, motivating others) }\end{array}$} \\
\hline Support and Obstacles Grids & $\mathrm{C} 2$ & SE & \\
\hline Voting by moving & $\mathrm{C} 3$ & SE & \\
\hline \multicolumn{4}{|l|}{ Impacts } \\
\hline Most significant change & D1 & & \multirow{2}{*}{$\begin{array}{l}>80 \% \text { of significant changes occurred, the impact } \\
\text { of the training, either on the participants } \\
\text { themselves, students or schools }\end{array}$} \\
\hline Mentor Survey & D2 & & \\
\hline
\end{tabular}

** $C L=$ Cluster learning, $O=$ On the job learning, $S E=$ Sharing Experience 
Eka Dewi Nuraeni et al.

\section{RESUlT AND DISCUSSION}

The results of training evaluation in the limited trial phase can be seen in the table below.

Table2. Results of Evaluation and Criteria in Limited Trial Phase

\begin{tabular}{|c|c|c|}
\hline Instrument & Success Criteria & Limited Trial Phase Result \\
\hline \multicolumn{3}{|l|}{ Reaction } \\
\hline Smile sheet & $\begin{array}{l}>90 \% \text { of participants feel } \\
\text { very happy or happy }\end{array}$ & $99 \%$ of participants feel very happy or happy \\
\hline $\begin{array}{l}\text { Training } \\
\text { Evaluation by } \\
\text { participants }\end{array}$ & $\begin{array}{l}\text { Effectiveness }>80 \% \\
\text { Relevance }>80 \%\end{array}$ & $\begin{array}{l}\text { Effectiveness of CLOSER } 89 \% \\
\text { Relevance of CLOSER } 88 \% \\
\text { Effectiveness of SLIM } 90 \% \\
\text { Relevance ofSLIM } 90 \%\end{array}$ \\
\hline \multicolumn{3}{|l|}{ Learning } \\
\hline $\begin{array}{l}\text { Pre-Test/Post } \\
\text { test }\end{array}$ & $\begin{array}{l}\text { T-test }<0.05 \text { ( significant) } \\
\text { Effect size }>0.8 \text { (big) }\end{array}$ & $\begin{array}{l}\text { T-test } 6.8 \times 10^{-5} \text { (significant) } \\
1.22 \text { (big) }\end{array}$ \\
\hline $\begin{array}{l}\text { Supervision of } \\
\text { implementation }\end{array}$ & $\begin{array}{l}>80 \% \text { implements training } \\
\text { on the job learning } \\
\text { The average result of } \\
\text { supervision on good } \\
\text { criterion }(66-80 \%) \text { or very } \\
\text { good }(81 \%-100 \%)\end{array}$ & $\begin{array}{l}100 \% \text { participants implements training on the job } \\
\text { learning } \\
\text { The average result of supervision is } 79 \% \text { (good criterion) }\end{array}$ \\
\hline $\begin{array}{l}\text { Self-assessment } \\
\text { and assessment } \\
\text { of mentor / } \\
\text { supervisor }\end{array}$ & $\begin{array}{l}>80 \% \text { of the participants } \\
\text { who implemented the } \\
\text { training were declared } \\
\text { competent }\end{array}$ & $\begin{array}{l}100 \% \text { participants who implemented the training were } \\
\text { declared competent ( two participants were given a week } \\
\text { extra time) }\end{array}$ \\
\hline \multicolumn{3}{|l|}{$\begin{array}{l}\text { Behavior } \\
\text { Changing }\end{array}$} \\
\hline $\begin{array}{l}\text { Group } \\
\text { discussion }\end{array}$ & \multirow{3}{*}{$\begin{array}{l}>80 \% \text { of participants } \\
\text { implement follow-up plans } \\
\text { There are behavioral } \\
\text { changes (continuing to } \\
\text { implement activities, } \\
\text { overcoming barriers with } \\
\text { available support, } \\
\text { motivating others) }\end{array}$} & $\begin{array}{l}\text { Behavior Changing: } \\
\text { - }\end{array}$ \\
\hline $\begin{array}{l}\text { Support and } \\
\text { Obstacles Grids }\end{array}$ & & $\begin{array}{l}100 \% \text { of participants implement follow-up plans } \\
-\end{array}$ \\
\hline $\begin{array}{l}\text { Voting by } \\
\text { moving }\end{array}$ & & $\begin{array}{l}\text { Identifying obstacles and trying to solve them } \\
\text { - } \\
\text { Identify the things that support } \\
\text { - } \\
\text { Willing to attend other training at their own expense }\end{array}$ \\
\hline
\end{tabular}

From the table above it can be seen that both at the reaction level, learning, and behavioral changes, has exceeded the specified success criteria. At the reaction level, participants love CLOSER training and SLIM teaching materials and assess that CLOSER and SLIM are effective and relevant to the work of the participants. At the learning level, CLOSER training and SLIM teaching materials can increase knowledge significantly with large effect size, and make teachers competent in implementing learning in the classroom. At the level of behavior change, the participants implement the action plan that has been made, implement the follow-up plan, identify the obstacles and try to solve them, identify the things that support, try to pass on to others, will continue to implement SLIM and CLOSER and are willing to attend other training at their own expense.

Similarly, under the wider scope with a larger sample, it is found out that CLOSER training with SLIM teaching materials can improve teacher competence. With the achievement of these competencies, the performance of teachers and schools can increase. This is in line with the results of research Khan et al (2011) that Training \& Development and proper training design has a significant and positive effect on organizational performance.

From the training evaluation results both at the reaction level, learning and behavioral changes, it has exceeded the specified success criteria. At the reaction level, during cluster learning, 94\% of participants feel very happy or happy, CLOSER effectiveness $=91 \%$, CLOSER relevance $=88 \%$, SLIM effectiveness $=90 \%$, and SLIM relevance $=89 \%$.

At the learning, level is obtained t-test $7.3 \times 10-7$ (significant) and effect size 1.4 (large). Given that cluster learning is adapted from in-service training, this is in line with the results of the Bala and 
Mustafa Arslan meta-analysis (2015) that one way to increase classroom activity is through in-service training (IST). The conclusions obtained include IST training conducted in the area proven to be very effective.

At the on the job learning stage, $100 \%$ of participants implement follow-up plans with varying outcomes. At this stage, participants review the training materials and implement them in their respective schools. The existence of the supervision program makes the participants more recognize the weakness and lack of learning. This implementation is an initial step of habitation so that sustainable implementation can improve the performance of teachers and organizations. This can be seen also from the results of research Khan et. al, that on the job learning has significant and positive effects on organizational performance. On the job, learning can improve organizational performance. In addition, On the Job Training is very effective and save time and cost in improving competence. Delivery style has a significant and positive effect on organizational performance. On the job, learning can improve organizational performance.

At the level of behavior change, all participants (100\%) create action plans with varying levels of performance. At the impact level, 85\% of participants undergo the most significant changes experienced by participants with impacts after the training can be grouped into 1) the impact on the teacher, 2) the impact on the learner, and 3) the impact of the learning process. The causes of impacts that occur as a result of the training are 1) the right strategy when cluster learning, 2) the existence of supervision process, 3) sharing experience, 4) the material and reading the material. The right strategy when cluster learning is through the process of discussion and simulation methods, games, role models provided in the training are easy to digest and provoke a great curiosity to apply better.

Changes in teachers can be seen, now using learning methods so more varied, more spirit, creative in giving lessons to students. Changes in students such as tackling enthusiastic students on the lesson, decreasing the level of delinquency of students in the classroom, increasing the spirit of both students and teachers in carrying out the process of Teaching and Learning Activities.

The expert team observed during Cluster Learning and Sharing experience. At the time on the job learning, the team of experts visited the school to make observations. CLOSER specialists assigned a score of 3.7 on scale 4 to the implementation of the training. There are no CLOSER related entries. CLOSER specialists suggest an additional document like a module/handbook for the facilitator in case the training is to be massive. This handbook aims to guide and minimize the gap between facilitators. The SLIM expert assigns a value of 3.8 on a scale of 4 to the use of SLIM teaching materials. Input is preferred from the language editing factor.

Prior to the revision, the researchers discussed with expert teams to provide explanations and clarifications. Revisions are preferred for smoother language and presentation. The model is revised to produce CLOSER Version 4 and SLIM Version 4. Experts CLOSER suggests that an additional document, module/handbook for the facilitator be put in place if the training is to be carried out in a massive manner. This handbook aims to guide and minimize the gap between facilitators.

\section{CONClusion}

CLOSER training with SLIM teaching materials used to improve teacher competence in learning in private Islamic Junior High School in Karawang Regency gives the following results.

CLOSER training reaction with SLIM teaching materials shows satisfactory reaction levels which can be seen from the value of satisfaction, effectiveness, high relevance (94\% of participants feel very happy or happy, CLOSER effectiveness $=91 \%$, CLOSER relevance $=88 \%$, SLIM effectiveness $=$ $90 \%$, and SLIM relevance $=89 \%$. At the level of learning, there is a significant increase in knowledge as well as the achievement of targeted competencies.

At the level of behavior change, $100 \%$ of participants implement follow-up plans with achievements varied. Behavior change is demonstrated by continuing to apply the training results and disseminating them, identifying obstacles and trying to solve them, identifying the supportive things, and willing to attend other training at their own expense. At the yield/impact level, $80 \%$ of participants experienced significant changes. Impact on teachers can be seen from the increasing ability of teaching, learning management and motivation. Students become enthusiastic, morale motivation increases, and misbehavior in the class declines. The impact on the foundation is the provision of learning media tools for teachers to implement SLIM CLOSER. 


\section{REFERENCES}

Amstrong, Michael. A Handbook of Human Resources Management Practice.London \& Philadelphia. Kogan Page. 2006. p.575

Balta, Nuri \& Mustafa Arslan. The Effect of In-Service Training Courses on Teacher Achievement: A Meta-analysis Study. Journal of Education and Training Studies Vol.3,No.5 September2015 ISSN 2324-805X E-ISSN 2324-8068

Branch, Robert M. Instructional Design: The ADDIE Approach, (New York: Springer Science\& Business Media:2009) , p.8

Gall, M. D., Borg, W. R., \& Gall, J.P. (1996). Educational research: An introduction. Longman Publishing.

Khan, Raja Abdul Ghafoor, Furqan Ahmed Khan, Dr. Muhammad Aslam Khan. Impact of Training and Development on Organizational Performance. Global Journal of Management and Business

Research Volume 11 Issue 7 Version 1.0 July 2011. Global Journals Inc. (USA) Print ISSN: 0975-5853

Kaswan. Pelatihan dan Pengembangan Untuk Meningkatkan Kinerja SDM. (Bandung, Penerbit Alfabeta. 2011). p. 2.

Mulyatiningsih, Endang. Metode Penelitian Terapan Bidang Pendidikan (Bandung. Penerbit Alfabeta. 2013) pp.163-164

Rothwell, William J. \& H.C Kazanas. Planning and Managing Human Resources. Strategic Planning for Human Resources Management. 2nd edition. (Massachusetts. Publish by Human Resources Development Press. Inc. 2003). p.353

Sims, Ronald R,.Organizational Success through Effective Human Resources Management. Westport, Connecticut • London. Quorum Books. 2002 pp. 181-191

Wiggins, Grant, and Jay McTighe. The Understanding by Design. Guide to Creating High-Quality Units. (Virginia. ASCD. 2011). pp.7-8 